\section{Tax Compliance: Factors that Influence Taxpayer Invoice Requests in Portugal}

\author{
João Minas Pinheiro ${ }^{1}$ \\ Tiago Andrade Diogo ${ }^{2}$ (B) \\ António Samagaio ${ }^{3}$
}

\begin{abstract}
Purpose - This study analyzes citizens' behavior in relation to sales invoices in the context of collaborating with the Portuguese Tax Administration on tax compliance. Specifically, we address two research questions: i) we identify the determinants that lead to individual taxpayers requesting invoices with(out) a tax identification number, and ii) we identify the sociodemographic characteristics that are associated with these behaviors.
\end{abstract}

Theoretical framework - This research draws on the insights of tax compliance and empirical work on the motivations for taxpayers to request a sales invoice.

Design/methodology/approach - The study uses the survey method and data were collected through a questionnaire made available on an electronic platform. The study applies principal component analysis and cluster analysis to a sample of 240 Portuguese individual taxpayers.

Findings - The results show that invoice requests is a complex phenomenon, since it is associated with intrinsic (e.g. social norms) and extrinsic (e.g. tax benefits) motivations of taxpayers. The results also indicate that the "lottery invoice" is a factor with little relevance. Our study identified four factors that synthesize taxpayer behaviors: the positive influence index, the inhibition index, the disengagement/ distance index, and the indulgence index. Moreover, the results show that a high heterogeneity of taxpayer behaviors, since five clusters were identified, as well as the influence of some sociodemographic characteristics (age and education), which should be considered when interpreting the behaviors.

Practical \& social implications of research - The results obtained could be used by the government and tax authority to design and implement current and/or future measures to combat tax evasion and interact with taxpayers.

1. Instituto Superior de Economia e Gestäo, Universidade de Lisboa, Lisbon, Portugal

2. Instituto Superior de Economia e Gestão, Universidade de Lisboa, ADVANCE, Lisbon, Portugal

3. Instituto Superior de Economia e Gestão, Universidade de Lisboa, ADVANCE, Lisbon, Portugal

\section{How to cite:}

Pinheiro, J. M., Diogo, T. A., Samagaio, A. (2021). Tax Compliance: factors that influence taxpayer invoice requests in Portugal. Revista Brasileira de Gestão de Negócios, 23(4), p.619-634.
Received on:

07/29/2020

Approved on:

03/03/2021

Responsible Editor:

Prof. Dr. Ilídio Lopes

\section{Evaluation process:}

Double Blind Review

\section{Reviewers:}

Cidália Lopes; One of the reviewers decided not to disclose his/her identify.

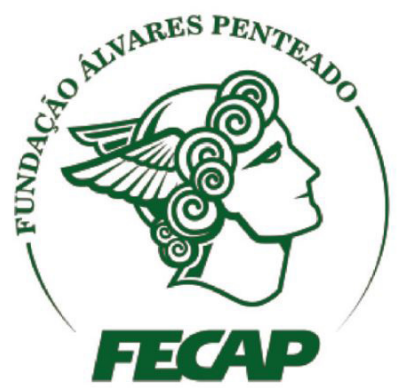

Revista Brasileira de Gestáo de Negócios

https://doi.org/10.7819/rbgn.v23i4.4133 
Originality/value - This work contributes to the knowledge of the reasons that lead citizens to cooperate with tax authorities in pursuing tax evasion, revealing that the attitude of asking for an invoice with a tax identification number is a complex phenomenon. The study allows us to broaden the knowledge on the positive rewards of tax compliance, which is an under-studied field of tax research.

Keywords - invoice, tax compliance, taxpayer behavior, tax benefits.

\section{Introduction}

Taxes are undoubtedly the most important source of revenue for governments. Collecting tax revenues is a major problem for all countries around the world. However, governments tend to make efforts to reduce lost tax revenues. On the other hand, most taxpayers try to optimize their tax debts by engaging in tax planning, tax evasion/fraud, or tax avoidance actions. The main purpose is always to reduce tax debts.

Tax authorities cannot rely on full tax compliance because despite most taxpayers being willing to pay their share (Diogo, 2018; Kirchler, 2007), some engage in illegal actions to reduce their tax debts (Alm, 2019). On this topic, Lamberton, De Neve, and Norton (2018) argue that most taxpayers prefer not to pay taxes, resulting in a tax gap, which is tax revenues lost due to tax noncompliance, such as the tax gap of $£ 31$ billion in the UK (Her Majesty's Revenue \& Customs [HMRC], 2020). Richardson and Sawyer (2001) alert us to the increasing tax gap, making it an important matter of discussion for all governments.

In recent years, the Portuguese Tax Administration (PTA) has adopted several measures to reduce tax non-compliance and promote taxpayers' cooperation to improve voluntary tax compliance. In 2012, the Portuguese government ordered most firms to use electronic invoicing systems and automated reporting. Meanwhile, the PTA created an electronic system - e-invoice - for taxpayers to monitor their tax deductions at any time. The e-invoice system has been crucial to maintain a low tax gap, especially the value added tax (VAT) gap. There are two points to highlight: i) the Portuguese VAT gap has been decreasing since the implementation of e-invoice (13.7\% in 2014 to $7 \%$ in 2019 , always below the EU average of $14.3 \%$ in 2014 and $9.6 \%$ in 2019) (Center for Social and Economic Research [CASE], 2020), and ii) e-invoice granted an award to Portugal in 2013 - the $\mathrm{CIO}$ Award. E-invoice gave individual taxpayers the possibility to deduct $15 \%$ VAT in some activity sectors that are more prone to the shadow economy with the condition that taxpayers ask for an invoice-receipt with their tax identification number (TIN). In 2014, the Portuguese government went further and introduced a tax lottery to discourage deviant behaviors connected to the shadow economy, allowing taxpayers the possibility to earn prizes such as cars (previously) and treasury certificates. However, this citizen cooperative action is not mandatory, since people are not legally obliged to request an invoice with their TIN.

In 2011, Portugal required a bailout package, an agreement which committed the country to increase its tax burden significantly. This context made it urgent for the e-invoice system and other measures adopted by the PTA to increase tax collection effectiveness. Thus, the purpose of our paper is to analyze citizens' behavior in relation to sales invoices in the context of collaborating with the PTA on tax compliance. Specifically, we address two research questions: i) we identify the determinants that lead individual taxpayers to request invoices with(out) a TIN, and ii) we identify the sociodemographic characteristics that are associated with these behaviors. Principal component factor analysis and cluster analysis were used to perform the analysis. Both methods were applied to a sample of 240 Portuguese citizens whose data were collected through a questionnaire survey.

Feld, Frey, and Torgler (2006) point out that there is a limited amount of empirical and experimental evidence to investigate in detail the impact of positive rewards on tax compliance. Furthermore, the scarce literature on tax compliance examines the individual impact of a specific incentive (e.g. lotteries) on requests for invoices with a TIN. Except for Wilks, Cruz, and Sousa (2019), the literature does not analyze the multiple factors that can influence these behaviors. A better understanding of taxpayer attitudes and behaviors is crucial for promoting cooperation between taxpayers and tax administrations (Mitu, 2016). Moreover, identifying taxpayers' behavior is critical to addressing tax non-compliance (Devos, 2014). Thus, this paper aims to provide new insights into what motivates citizens to cooperate with the tax authority in pursuing VAT evaders. 
Following this introductory section, Section 2 provides the literature review. Section 3 describes the research model, research variables, and sample. Section 4 presents the empirical results, and Section 5 focuses on the discussion. Section 6 offers the conclusions, contributions, and future research topics.

\section{Literature Review}

\section{I Tax compliance}

The main goal of collecting taxes is to satisfy the government's financial needs (Pereira, 2018). Also, taxes are an important matter for society because of social norms (Bobek, Hageman, \& Kelliher, 2013; Bobek, Roberts, \& Sweeney, 2007), since taxes are the main point of social contracts (Brockmann, Genschel, $\&$ Seelkopf, 2015). The more effective tax authorities are at managing tax compliance, the smaller the tax gap will be (Richardson \& Sawyer, 2001). The tax gap is "the difference between tax collected and the tax that should be collected" (HMRC 2012, p. 3). This definition is also compatible with the one used by the IRS (Raczkowski, 2015). The main literature refers to the core features for the abovementioned definition of the concept of tax gap (Robbins \& Kiser, 2020). HMRC used an older definition: "the tax gap measures the amount of tax we ultimately fail to collect, or, alternatively the amount of uncorrected non-compliance" (Palan, Murphy, \& Chavagneux, 2010, p. 66). According to Murphy (2008), and the HMRC's point of view, the due amount of tax to be paid can be broken down into two components: 1) the part that is due if the letter of the law is complied with, and 2) the part that is due if the spirit of the law is also complied with. This situation can lead us to a specific tax gap - the expectation gap - as

[...] the difference between the headline or declared tax rate for companies, and the rate of tax they actually pay. This gap is a measure of the difference between the contribution society expects business to make by way of tax paid, and what is actually paid. (Murphy, 2008, p. 4)

Increasing the level of tax compliance is now a major challenge for tax authorities and governments around the world (Agbetunde, Akinrinola, \& Odinakachi, 2020).

Regarding the definition of tax compliance, there is no single universally accepted definition (Devos,
2014). Several authors present their own definition of tax compliance (Balestrino \& Galmarini, 2003; Borrego, 2015; Devos, 2014; Diogo, 2018; James \& Alley, 2002; Kirchler, 2007; McBarnet, 2001; McKerchar, 2003; Organisation for Economic Co-Operation and Development [OECD], 2010; Roth, Scholz, \& Witte, 1989). Based on these authors, Diogo (2018) states that tax compliance occurs when taxpayers cumulatively submit, in due time their tax returns with the real value of earned income and expenses that is fiscally accepted and supported, and they pay the amount due by the end of the voluntary payment period and comply with their additional obligations as specified by the tax codes.

Regarding tax compliance research, Antinyan and Asatryan (2020) argue that there are several excellent literature reviews such as those of Alm (2019), Andreoni, Erard, and Feinstein (1998), Slemrod (2007; 2019), and Slemrod and Yitzhaki (2002). Additionally, we can mention Borrego (2015) and Diogo (2018) for research on tax compliance in Portugal and Devos (2014) in Australia. Borrego (2015), Devos (2014), and Diogo (2018) identify two major theoretical approaches to tax compliance: 1) economic deterrence theory and 2) fiscal and social psychology models.

Economic deterrence theory is linked to the economic crime theory of Becker (1968), which led to the papers by Allingham and Sandmo (1972), Srinivasan (1973), and Yitzhaki (1974). Economic deterrence theory assumes that taxpayers are rational in aiming to maximize their expected utility. In order to maximize their expected utility, they have to decide if they are willing to report all income or risk being audited and fined for underreporting income. In order to dissuade taxpayers from intentional tax non-compliance, the main measures, in terms of tax legislation, are fines, constituting one of the variables of the AS model, and carrying out tax audits with an associated probability. Tax compliance models, based on economic theory, thus instill control and punishment of non-compliant taxpayers as measures to educate and deter taxpayers from defaulting on their tax obligations (Chu, 1990; Kirchler, 2007; Sanson, Montgomery, Gault, Gridley, \& Thomson, 1996). Since the papers by Allingham and Sandmo (1972) and Yitzhaki (1974), several studies have been developed based on economic deterrence theory. However, these studies have inadequately understood tax compliance behavior due to their weak predictive reliability (Alm, 2019; Borrego, 2015; Devos, 2014; Diogo, 2018). Nevertheless, Allingham and Sandmo 
(1974) and Yitzhaki (1974) count more than 6400 and 1500 citations respectively in Google Scholar.

Social psychology has been used to develop a mechanism for understanding human behavior. Social psychology models aim to analyze how people shape their expectations and how these influence their personal choices, with several studies carried out in the field of methodological procedures and tax compliance determinants (Borrego, 2015; Devos, 2014; Diogo, 2018; McKerchar, 2003).

One important study that uses the fiscal and social psychology approach is that of Schmölders (1959), who presents the concept of tax mentality as "individual resistance to direct taxation” (Schmölders, 1959, p. 342), which can vary across countries. It is also important to refer to Strümpel's (1969) study, which introduces the willingness to cooperate variable in a tax compliance model. During the 1970s, other studies were developed, in particular that of Spicer (1974), who developed the concept of exchange equity (Devos, 2014). From the 1980s, it is crucial to mention Icek and Ajzen's research, which presents the theory of reasoned action and theory of planned behavior (e.g. Ajzen \& Fishbein, 2005), in which taxpayers' behavior is influenced by their intentions - attitudes towards behavior and their awareness of subjective norms. Subjective norms are also an interesting topic of research within the field of tax compliance (e.g. Onu \& Oats, 2016). Other variables have emerged over time, such as tax complexity and tax morale.

Concerning tax complexity, Jackson and Milliron (1986) introduced this as a key tax compliance variable. Since the government's goal is to promote voluntary tax compliance in order to increase the efficiency of tax administration, we should note that non-compliance can be grouped into involuntary and intentional non-compliance. The former can emerge when taxpayers have difficulties dealing with tax law due to a lack of tax knowledge or tax education skills. Regarding this topic, we can cite Borrego, Lopes, and Ferreira (2017), who applied a survey in Portugal and argued that tax professionals, who are very important players in the tax system (Pickhardt \& Prinz, 2014), are more prone for non-compliance when they are responsible for the tax obligations of medium-sized companies in a high tax complexity context. Furthermore, the authors showed evidence that intentional non-compliance occurs when employees are stressed by their clients as well as their employers (companies with a finance department responsible for accounting and taxation issues).
Regarding tax morale, Schwartz and Orleans (1967) conducted a pioneer study about this variable. Sá (2013) cited Cummings, Martinez-Vazquez, McKee, and Torgler (2009, p. 448) to present the definition of tax morale as "the intrinsic motivation to pay taxes arising from the moral obligation to pay taxes as a contribution to society." Sá, Gomes, and Martins (2016) presented the tax morale factor broken down into five types: demographical, economical, sociological and behavioral, psychological, and political. Concerning the measurement of tax morale, several authors use questions retrieved from the World Values Survey (Daude, Gutierrez, \& Melguizo, 2013; Diogo, 2018; Sá et al., 2016).

\subsection{Motivations to request a sales invoice}

Governments, with the cooperation of tax administrations, have an incentive to develop strategies in order to increase tax revenues, especially when budget deficits persist. There is a set of variables which can motivate taxpayers to comply and cooperate with tax administrations. These variables have been studied over the years by several researchers (Devos, 2014).

A common strategy of businesspeople involved in VAT fraud consists of not issuing invoices and not recording transactions, thus saving the amount corresponding to VAT (Fabbri \& Wilks, 2016). In many countries, invoices with a TIN are considered well-documented proof of the existence of taxable transactions (Hemels \& Fabbri, 2013). Once an invoice has been issued, it is very hard to deny the occurrence of the sale, as well as to avoid reporting it to the government.

VAT, like other indirect taxes, is real or objective because it does not consider the taxpayers' conditions and personal situation (Pereira, 2018). It also does not give taxpayers any sense of ownership (Lamberton et al., 2018). The difficulty for taxpayers to understand taxes does not simplify the awareness process related to the importance of and need to request an invoice. Without the government's specific intervention, clients/taxpayers not only do not receive benefits, but can also face high social pressures and moral costs when requesting an invoice if the social norm is to not request one (Hemels \& Fabbri, 2013).

VAT evasion is widespread and involves significant tax losses (Webley, Adams, \& Elffers, 2006). Thus, several countries seek to encourage taxpayers to request invoices in order to force sellers to declare and pay taxes 
due to the government. An effective incentive to request invoices allows the government to save resources in the supervision of defaulting taxpayers. Taxpayers assume the role of unpaid inspectors working for the government, promoting tax compliance (Hemels \& Fabbri, 2013).

To encourage the issuance of invoices, some countries (e.g. Belgium and Italy) have tried to force taxpayers to request an invoice by imposing sanctions, but this solution has been difficult to implement and ultimately ineffective (Fabbri \& Wilks, 2016). Andreoni et al. (1998) observed that the use of the "stick" as a coercive measure to enforce tax compliance may not have the desired impact in the long run.

Given the widespread problem of VAT fraud, which involves tax losses (Webley et al., 2006), there is growing interest in rewards-based measures that complement traditional deterrent tools (Feld \& Frey, 2007). Rewards can be more effective than punishments in eliminating unwanted behavior or motivating desired behavior as they are perceived as supportive (Torgler, 2003). Rewards may be material or immaterial (Brockmann et al., 2015).

The best-known material rewards consist of lotteries. These rewards have been implemented in some European Union member states, such as Malta (1997), Slovenia (2013), and Portugal (2014) (Fooken, Hemmelgarn, \& Herrmann, 2014). The incentive is to make the invoice a lottery ticket, giving taxpayers the chance to participate in a draw (Fooken et al., 2014). According to the author, the costs incurred by tax administrations, which is the cost of paying the premiums and managing the lottery, are in some cases surpassed by the additional revenue obtained with the increase of the taxable base and by a citizen-police effect that detects the companies that commit VAT fraud. Moreover, a tax lottery may also serve other purposes, such as serving as a vehicle of communication to citizens to emphasize the importance of paying taxes (Fooken et al., 2014). Alm, Jackson, and McKee (1992) conducted a field experiment on tax lotteries. The results suggest that a lottery effectively increases tax compliance compared with alternative reward strategies (fixed rewards vs. fewer audits). However, the strategy becomes unrealistic if the probability of winning is extremely high and the premium is low; today, tax lotteries are characterized by a low probability of winning and a high value premium. High rewards are materially attractive, because taxpayers tend to devalue the low probability of winning the prize. Taxpayers generally judge the attractiveness of lotteries by the premium size and not by the probability of success (Perez \& Humphreys, 2013).

In 1980, Bolivians were encouraged to demand invoices by granting a tax benefit in personal income tax (PIT) to partially offset the VAT paid (Bird, 1992). However, the measure was unsuccessful given the weak incentive to request invoices and the possibility of an agreement between the taxpayer and the seller not to pay the VAT, dividing the difference between both. Thus, if the reward is not high enough, taxpayers will not be prompted to request an invoice (Hemels \& Fabbri, 2013).

Immaterial rewards aim to increase taxpayers' ownership by giving them the ability to allocate tax revenues for specific purposes (Brockmann et al., 2015). According to the authors, contributions to social security are perhaps the most common example. In Spain, for example, it is possible for individual taxpayers to allocate $0.7 \%$ of PIT to the Catholic Church, charities, and other organizations (European Research Network on Philanthropy, no date). Portugal has a similar measure, which allows taxpayers to allocate $0.5 \%$ of PIT due to a private institution of social solidarity or a religious institution.

Recently, Wilks et al. (2019) found that requests for invoices with a TIN in Portugal were due to the desire to obtain a tax benefit, perceptions of justice, and civic duty. However, the authors state that future studies should add other variables that allow the theme to be explored more deeply.

\section{Research Design}

\section{I Research model}

The research model is underpinned by two research questions: i) what are the factors that motivate requests for invoices with a TIN? and ii) how do the sociodemographic characteristics of taxpayers explain this behavior? Drawing on the literature review, this study assumes that taxpayers' behavior is influenced by moral duty and rewards, among other motivations, and that tax actions are affected by combinations of sociodemographic attributes.

The purpose of this investigation is to produce knowledge that helps to understand and explain taxpayers' requests for invoices with or without a TIN. The work began by conducting a qualitative exploratory study, through a brainstorming process between the authors and two tax specialists, with the aim of assisting in the construction of the questionnaire. Then, a quantitative 
study was carried out, starting with the collection of data through the questionnaire and later analyzing the results in order to meet the two specific objectives.

\subsection{Survey}

Tax compliance, as well as taxpayer behavior, has been studied based on different methodologies (Kirchler \& Wahl, 2010). Kazemier and Van Eck (1992) report that when information on taxpayer behavior and tax fraud is sought, questionnaires are the best tool. Along the same lines, Kirchler and Wahl (2010) point out that the survey method using questionnaires is the most widely used technique for collecting data in tax compliance studies. This research tool is characterized as being a direct method (Schneider, 2005) that allows detailed information to be gathered on the dynamics underlying tax compliance (Andreoni et al., 1998). Additionally, the survey method is a powerful instrument to explore relatively complex and multifaceted phenomena as they occur in their natural context (e.g. to measure perceptions and beliefs that drive behaviors), while maintaining a degree of standardization required for quantitative analysis and to improve the specification of theory (Speklé \& Widener, 2018). In taxation research, the collection of data through surveys has been dominant since the 1980s (Diogo, 2018).

However, while data from questionnaires often have a lot of useful sociodemographic and behavioral information about taxpayers, the reliability of tax evasion data is highly suspect, as individuals may not remember their decisions when completing their income statement, they may not be totally sincere, or they may not be representative of all taxpayers (Alm, 2012). In order to obtain honest answers from the taxpayers, all the respondents were informed of the confidentiality of the answers and of the purely academic purpose of the questionnaire. The questionnaire was applied to individual taxpayers residing in Portugal.

The first stage involved outlining a primary version of the questionnaire, based on a brainstorming process using suitable language for the potential respondents and choosing questions that seemed most appropriate (Hill \& Hill, 2008). Any of these aspects constitutes a differentiated step in the construction of the questionnaire. Because of this, there is a potential possibility of failure, which is often verified when using this method of data collection (Foddy, 1996).

In order to ensure that all questions were properly understood by the respondents, as well as to ensure that there were no problems with the wording, the second stage consisted of the pre-test questionnaire, as suggested by Sekaran and Bougie (2016), applied to a limited number of volunteers in May 2017. The questionnaire was delivered in paper format, on which each of the volunteers reported their suggestions, difficulties found throughout the questionnaire, and the time it took them to respond. Based on the suggestions collected, the questionnaire underwent some important changes: 1) some questions were reformulated; 2) certain words were amended for better understanding, and 3) some issues were excluded in order to reduce the response time, and a maximum limit of twenty minutes was set at that point.

Once the questionnaire had been finalized, it was distributed online, without the presence of the researcher, because this could be considered intrusive and limit the full expression of the respondents, given the sensitive nature of the topic. This situation would lead to skewed data that inadequately represented the reality (Alm, 2012; Borrego, 2015; Diogo, 2018). The survey was applied through the Google Forms platform and the data were collected between May and August of 2017.

\subsection{Research variables}

The questionnaire was divided into two sections in order to collect data on independent and dependent variables. In the first section, we started with an introductory question that sought to understand how often the taxpayers requested an invoice with a TIN. Then, we identified the various factors that may influence requests for invoices with or without a TIN - the dependent variable. Whereas Wilks et al. (2019) considered six reasons for requesting invoices with a TIN, we used a questionnaire with 19 motivations, measured on a seven-point Likert scale, with one being "no influence" and seven being "full influence." Although the 19 items are an innovation of this research, we followed international studies in the area of tax compliance that measure questions based on a seven-point Likert scale (e.g. Jimenez \& Iyer, 2016). Table 1 details the determinants.

The literature has identified several sociodemographic variables (e.g. Devos, 2014; Torgler, 2007). Based on these, the second section comprises questions that allowed the respondents to be characterized in sociodemographic terms, namely regarding gender, age, education, tax training, and level of income - the independent variables. The tax training variable refers to the respondent's training in the 
Table 1

\section{Determinants of Requests for Invoices with/without a TIN}

\begin{tabular}{|c|c|c|c|c|c|}
\hline Determinants & $\mathbf{N}$ & Min & Max & Mean & $\begin{array}{c}\text { St } \\
\text { Deviation } \\
\end{array}$ \\
\hline E-invoice lottery & 224 & 1 & 7 & 2.09 & 1.78 \\
\hline Increases the tax benefit and thus contributes to a possible PIT refund & 228 & 1 & 7 & 5.22 & 2.09 \\
\hline Ensures that the taxes we pay go to the government & 229 & 1 & 7 & 4.33 & 2.09 \\
\hline Part of the taxes can be allocated to non-profit institutions & 217 & 1 & 7 & 3.55 & 1.97 \\
\hline $\begin{array}{l}\text { It is a duty of citizenship that increases justice and contributes to } \\
\text { combating fraud and tax evasion }\end{array}$ & 227 & 1 & 7 & 4.92 & 2.09 \\
\hline $\begin{array}{l}\text { It is not fair to pay more taxes because there are taxpayers who do not } \\
\text { meet their tax obligations }\end{array}$ & 220 & 1 & 7 & 5.03 & 2.14 \\
\hline It is a moral duty & 224 & 1 & 7 & 4.68 & 2.17 \\
\hline There is a reduction in the amount of billed goods or services & 208 & 1 & 7 & 4.21 & 2.36 \\
\hline Proximity to seller/service provider & 218 & 1 & 7 & 2.95 & 2.13 \\
\hline Do not remember the TIN & 210 & 1 & 7 & 2.08 & 1.97 \\
\hline Shame & 211 & 1 & 6 & 1.52 & 1.25 \\
\hline Very large queue of people behind me & 213 & 1 & 7 & 1.95 & 1.58 \\
\hline Benefit from a lower price of the good/service & 212 & 1 & 7 & 2.97 & 2.25 \\
\hline Considering it "right" not to pay taxes & 205 & 1 & 7 & 1.55 & 1.30 \\
\hline There is no PIT reimbursement when filing tax returns & 205 & 1 & 7 & 2.60 & 2.15 \\
\hline Being dissatisfied with the use of taxes paid by taxpayers & 213 & 1 & 7 & 2.66 & 2.24 \\
\hline Laziness & 207 & 1 & 7 & 2.29 & 1.86 \\
\hline It gives more work to the seller/service provider & 208 & 1 & 7 & 1.79 & 1.53 \\
\hline The seller/service provider is not familiar with the billing system & 202 & 1 & 7 & 1.74 & 1.43 \\
\hline
\end{tabular}

field of taxation. The level of income variable expresses the degree of comfort that the taxpayer has with their earned income.

Our study is a quantitative and explanatory one, and of course internal and measurement validity are relevant subjects. Some techniques were used to reduce response errors (a brainstorming meeting among the project researchers, a pre-test questionnaire, a cover letter explaining the purpose of the survey, the consistency of Likert-type scale scores) and non-response errors (followup procedures and mentioning the study was part of an academic research project).

\subsection{Sample}

The target population of this study was all individual taxpayers residing in Portugal who made purchases in 2017. The survey population is a segment of the target population characterized by two additional elements: they used digital applications to answer the questionnaire and are members of a social network (e.g. Facebook) or belong to the ISEG alumni network. The sample comprises 240 usable responses. Table 2 shows the sociodemographic characteristics of the sample. Firstly, regarding gender,
$56.3 \%$ of the respondents are women and $43.8 \%$ are men. Based on Clotfelter (1983), the taxpayers were grouped into four age groups. The age of the sample ranged from 19 to 76 years old; the mean age was 41 years. It was also found that almost $70 \%$ of the respondents were between 30 and 65 years old. Regarding the education level of the respondents, most had completed higher education (73.8\%). In addition, more than half of the sample did not have tax training (61.7\%). Regarding the income level, the typology adopted in the European Social Survey was followed, since asking about monetary income can be embarrassing for the respondent and trigger a dishonest answer. The results show that most respondents said that they could live with their current income $(47.5 \%)$ or live comfortably with their current income (27.5\%) and 19.2\% said they had difficulties living with their current income.

\section{Empirical Results}

\section{I Descriptive statistics}

The results reveal that $60 \%$ of the respondents request between 1 and 7 invoices with a TIN per week, 
Table 2

\section{Sociodemographic Characteristics of the Sample}

\begin{tabular}{lcr}
\hline \multicolumn{1}{c}{ Item } & N & $\%$ \\
\hline Gender & & \\
Male & 105 & 43.8 \\
Female & 135 & 56.3 \\
Age & & \\
Less than or equal to 29 years old & 67 & 27.9 \\
Between 30 and 45 years old & 84 & 35.0 \\
Between 45 and 65 years old & 82 & 34.2 \\
More than or equal to 66 years old & 7 & 2.9 \\
Tax training & & \\
Yes & 92 & 38.3 \\
No & 148 & 61.7 \\
Education & & \\
Basic education & 15 & 6.2 \\
Secondary education & 48 & 20.0 \\
Higher education & 177 & 73.8 \\
& & \\
Income & & \\
Income allows them to live comfortably & 66 & 27.5 \\
Enough to live on & 114 & 47.5 \\
Difficult to live with their current income & 46 & 19.2 \\
Very difficult to live with their current & 14 & 5.8 \\
income & & \\
\hline
\end{tabular}

approximately $23 \%$ request between 8 and 14 invoices with a TIN per week, and $10 \%$ do not ask for any invoices with a TIN. Regarding the activities in which the taxpayers ask for an invoice with a TIN to obtain a PIT benefit (equivalent to a portion of VAT payable on certain expenses), the results highlight the high weight of the accommodation, catering, and similar sector (87.1\%) and car repair shops, parts, and accessories (63.7\%). In the remaining sectors, the respondents request fewer bills.

Table 1 shows the descriptive statistics of the determinants of taxpayers' requests for invoices with or without a TIN. The main determinant is related to the PIT benefit (mean of 5.22), showing an economic motivation for requesting invoices with a TIN. Additionally, it is important to highlight the high averages related to determinants associated with social norms, such as ensuring that taxes paid go to the government; it being a duty of citizenship that increases justice and contributes to the fight against fraud and tax evasion; it not being fair to pay more taxes because there are taxpayers who do not fulfill their tax obligations; and it being a moral duty. Therefore, we find that taxpayers are heavily influenced by intrinsic motivations to request an invoice with a TIN. Finally, the reduced amount of goods appears as a factor that influences including a TIN in an invoice. The data from the 19 determinants specified in the survey present a Cronbach's alpha of 0.88 , showing that there is good internal consistency.

\subsection{Multivariate analysis}

In a first step, we analyzed the variability of the variables through a boxplot in order to identify possible outliers. The "Shame" and "Considering it 'right' not to pay taxes" factors had severe enough outliers and therefore were excluded from the multivariate analysis. Thereafter, our study uses principal component factor analysis to extract the factors with an eigenvalue greater than 1 . The orthogonal varimax method is used for rotating the variables with a factor loading greater than 0.4 . Four factors were identified as explaining $62 \%$ of the variance (Table 3). The KMO statistic with 0.776 and the Bartlett test with a p-value $<0.001$ do not support the hypothesis of the existence of an identity matrix and consequently the principal component analysis is an appropriate method of analysis. The designation of these four factors is as follows: positive influence index (Factor 1), inhibition index (Factor 2), disengagement/distance index (Factor 3), and indulgence index (Factor 4).

Figure 1 shows the association between the four factors and the gender, education, age, income, and tax training of the respondents. The results show that the characteristics present in the gender and tax training dichotomous variables have opposite behaviors in relation to the four factors, but all values are close to an average of zero. Except for two cases, the results show that the influence of the factors is moderate among the social characteristics analyzed (scores between -0.25 and 0.25 ), and there are no statistically significant differences between categories. The first exception concerns education level, where those with the lowest level of education agree more strongly with the positive factors that influence requests for an invoice than those with the highest academic qualifications [ $\mathrm{t}$ $(52.517)=2.538 ; \mathrm{p}<0.05]$. The second exception reports an inverse relationship between agreement with indulgence (factor 4) in invoice requests and age [Kruskal Wallis (2) $=12.559 ; \mathrm{p}<0.01]$; that is, older respondents agree less with the indulgence items than younger respondents.

The standard deviation associated with each determinant identified in Table 1 shows high heterogeneity 
Table 3

\section{Main Factors that Influence the Requests for Invoices}

\begin{tabular}{|c|c|c|c|}
\hline Items & $\begin{array}{c}\text { Standardized } \\
\text { loadings }\end{array}$ & $\begin{array}{l}\text { Cronbach's } \\
\text { alpha }\end{array}$ & $\begin{array}{l}\text { Variance } \\
\text { explained }\end{array}$ \\
\hline Factor 1 - Positive influence index & & 0.832 & 21.69 \\
\hline $\begin{array}{l}\text { It is a duty of citizenship that increases justice and contributes to combating fraud } \\
\text { and tax evasion }\end{array}$ & 0.864 & & \\
\hline It is a moral duty & 0.851 & & \\
\hline It ensures that the taxes we pay go to the government & 0.766 & & \\
\hline $\begin{array}{l}\text { It is not fair to pay more taxes because there are taxpayers who do not meet their tax } \\
\text { obligations }\end{array}$ & 0.712 & & \\
\hline Part of the taxes can be allocated to non-profit institutions & 0.605 & & \\
\hline It increases the tax benefit and thus contributes to a possible PIT refund & 0.470 & & \\
\hline Factor 2 - Inhibition index & & 0.729 & 15.25 \\
\hline The seller/service provider is not familiar with the billing system & 0.854 & & \\
\hline It gives more work to the seller/service provider & 0.824 & & \\
\hline Very large queue of people behind me & 0.440 & & \\
\hline Factor 3 - Disengagement/distance index & & 0.701 & 14.12 \\
\hline Being dissatisfied with the use of taxes paid by taxpayers & 0.801 & & \\
\hline There is no PIT reimbursement when filing tax returns & 0.790 & & \\
\hline Benefit from a lower price in the good/service & 0.531 & & \\
\hline Laziness & 0.524 & & \\
\hline Factor 4 - Indulgence index & & 0.592 & 10.99 \\
\hline Billed goods or services have a reduced amount & 0.829 & & \\
\hline Proximity to seller/service provider & 0.619 & & \\
\hline
\end{tabular}

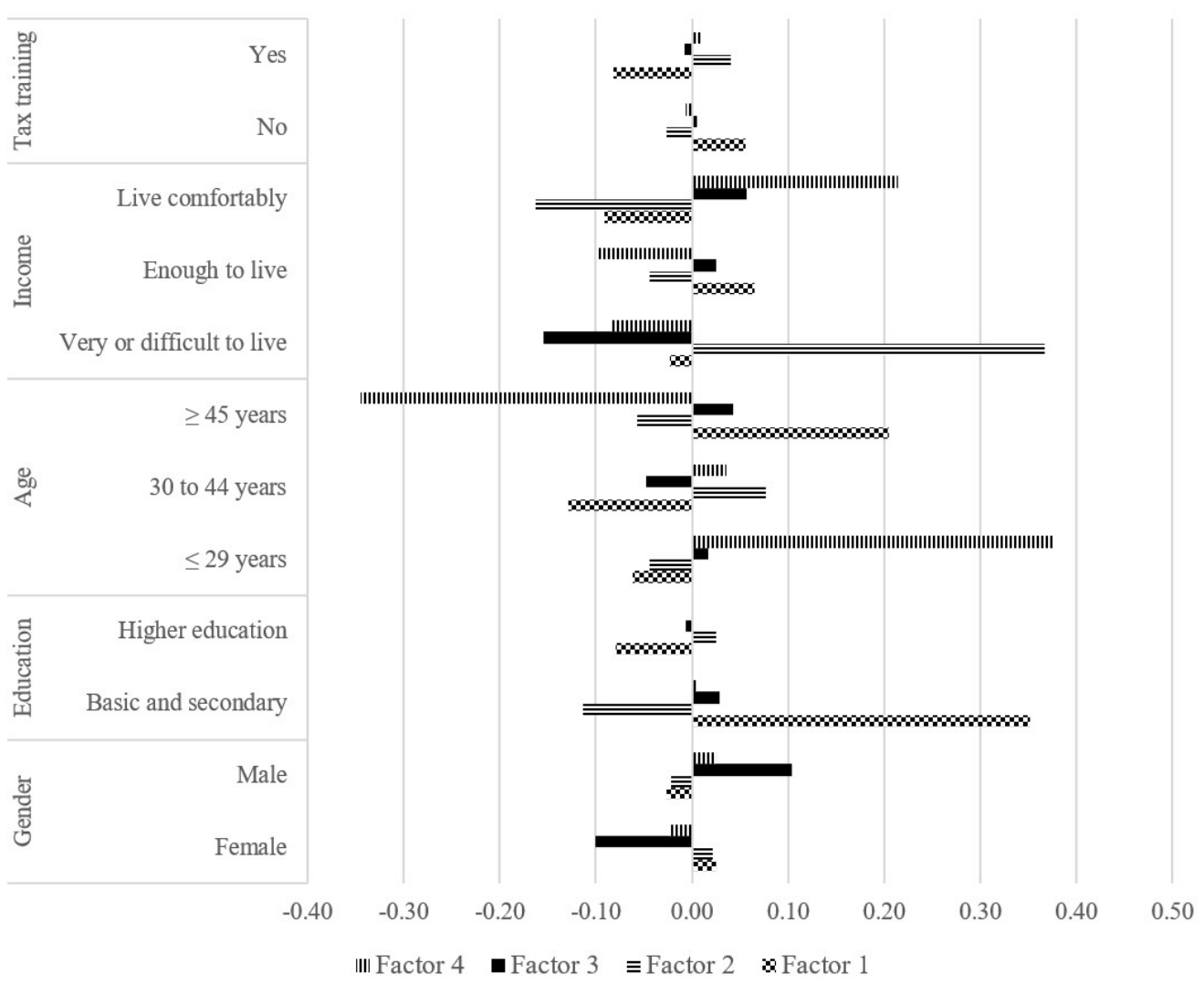

Figure 1. Social characterization of factors 
in the responses. Devos (2014) and Torgler (2007) state that sociodemographic factors determine the tax behavior of taxpayers. However, tax behavior is a complex and dynamic phenomenon, which may interact differently with the sociodemographic characteristics of taxpayers. Consequently, the cluster analysis allows a more holistic view on the subject, since the combination of multiple sociodemographic characteristics of taxpayers may be associated with identical behaviors in relation to requests for invoices with or without a TIN. Therefore, we used a two-step cluster analysis, which is a technique designed to create configurations, taxonomies, and strategic groups (Fiss, 2011). This method assumes that in a sample similar or different objects or cases may coexist. The objective is to organize cases into groups, where there is a high degree of similarity between cases in the same group, and high divergences between cases belonging to different groups (Janssens, Wijnen, Pelsmacker, \& Kenhove, 2008). Cases are classified into different clusters based on their values in a set of attributes (Pastor, 2010). In the first step, several hierarchical cluster analyses using Ward's minimum variance method and the squared Euclidian distance suggested a five-cluster solution. All measures were standardized in this work. The second step involved a K-means cluster analysis, based on the centroid values of previous hierarchical analysis as seeds. Table 4 presents the final solution of the cluster analysis.

The solution includes two groups with the same dimension (clusters 1 and 3), two with similar dimensions (clusters 2 and 4), and one smaller group (cluster 5). Cluster 1 covers cases that show a higher positive influence index and a lower indulgence index in the invoice requests. Cluster 2 presents negative scores in all factors, with special emphasis on the positive influence index in the requests for invoices with a TIN. Thus, the cases included in this group indicate that requests for invoices with or without a TIN were scarcely influenced by the four factors identified in this study. Cluster 3 comprises the cases with a low inhibition index and a high distance index in the invoice requests. Cluster 4 contains cases with high indulgence and inhibition indices, as well as respondents with a lower disengagement index. Finally, Cluster 5 comprises cases with high disengagement and inhibition indices.

Clusters 1 and 3 have opposite sociodemographic characteristics, as shown in Table 5. Cluster 1 has the highest number of women, older individuals, taxpayers with basic and secondary education levels, individuals finding it difficult or very difficult to live with their current income, and those with tax training. Cluster 3 has the largest number of men, the youngest individuals with the highest academic qualifications, individuals living reasonably well or comfortably with their current income, and those without training in the tax field.

\section{Discussion of the Results}

The results show that invoice requests are associated with the intrinsic motivations of taxpayers related to social norms and living in the community (e.g. it is a duty of citizenship that increases justice and contributes to combating fraud and tax evasion). As a second finding, the extrinsic motivation is evidenced in the taxpayers' behavior being positively influenced by the existence of a tax benefit in terms of PIT payable. As Wilks et al. (2019) found, our results also indicate that the "lottery invoice" (a measure implemented in several countries) is a factor that is of little relevance in taxpayers' requests for invoices. The literature indicates that unwanted behaviors of taxpayers can be minimized through material or immaterial rewards (Brockmann et al., 2015); but if the reward is not high enough, taxpayers will not be induced to request an invoice (Hemels \& Fabbri, 2013). In this context, the results of our study

Table 4

\section{Cluster Analysis Results}

\begin{tabular}{lcccccc}
\hline \multicolumn{1}{c}{ Configuration } & Cluster 1 & Cluster 2 & Cluster 3 & Cluster 4 & Cluster 5 & $\begin{array}{c}\text { ANOVA } \\
\text { F-value }\end{array}$ \\
\hline Positive influence index & 0.651 & -1.425 & 0.198 & 0.142 & 0.179 & $39.945^{*}$ \\
Inhibition index & -0.392 & -0.029 & -0.674 & 0.613 & 1.865 & $49.896^{*}$ \\
Disengagement/distance index & -0.604 & -0.341 & 0.857 & -0.795 & 1.397 & $61.213^{*}$ \\
Indulgence index & -0.775 & -0.415 & 0.432 & 1.151 & -0.330 & $35.731^{*}$ \\
$\mathrm{~N}$ & 41 & 29 & 41 & 27 & 15 & \\
\hline
\end{tabular}

Note: ${ }^{\star} \mathrm{p}<0.001$ 
Table 5

\section{Social Characterization of Clusters (\%)}

\begin{tabular}{|c|c|c|c|c|c|c|}
\hline & & Cluster 1 & Cluster 2 & Cluster 3 & Cluster 4 & Cluster 5 \\
\hline \multirow[t]{2}{*}{ Gender } & Female & 32.1 & 21.8 & 20.5 & 17.9 & 7.7 \\
\hline & Male & 21.3 & 16.0 & 33.3 & 17.3 & 12.0 \\
\hline \multirow[t]{3}{*}{ Age } & $\leq 29$ years old & 14.6 & 14.6 & 39.0 & 24.4 & 7.3 \\
\hline & 30 to 44 years old & 26.2 & 23.0 & 23.0 & 19.7 & 8.2 \\
\hline & $\geq 45$ years old & 37.3 & 17.6 & 21.6 & 9.8 & 13.7 \\
\hline \multirow[t]{2}{*}{ Education } & Basic and secondary education & 35.7 & 10.7 & 32.1 & 14.3 & 7.1 \\
\hline & Higher education & 24.8 & 20.8 & 25.6 & 18.4 & 10.4 \\
\hline \multirow[t]{3}{*}{ Income } & Very/difficult to live & 33.3 & 20.0 & 6.7 & 26.7 & 13.3 \\
\hline & Enough to live & 27.6 & 15.8 & 30.3 & 15.8 & 10.5 \\
\hline & Live comfortably & 21.3 & 23.4 & 34.0 & 14.9 & 6.4 \\
\hline \multirow[t]{2}{*}{ Tax training } & No & 26.4 & 16.5 & 30.8 & 15.4 & 11.0 \\
\hline & Yes & 27.4 & 22.6 & 21.0 & 21.0 & 8.1 \\
\hline
\end{tabular}

corroborate the importance of the material incentive of tax benefits, to the detriment of the other "lottery invoice" incentive. This finding is contrary to the view of some authors (e.g. Alm et al., 1992; Fooken et al., 2014), who have argued that a lottery could have a positive effect on tax compliance, a fact that our study does not corroborate. Indeed, positive rewards may, under certain conditions, crowd out threat-based or norm-based motivations for tax compliance (Fooken et al., 2014). While excessive fear of the tax authorities may alienate taxpayers, excessive rewards may also inadvertently erode compliance by reducing the deterrence value of audits and fines or by obscuring the obligatory character of taxation. Obviously, governments should make tax compliance as simple as possible. Yet they should not necessarily make it positively rewarding for the individual taxpayer. Some activities may have community-building power precisely because they are not completely painless, including death and taxation.

Our study identified four factors that synthesize the behaviors of taxpayers in relation to requests for invoices with or without a TIN, namely, the positive influence index, the inhibition index, the disengagement/ distance index, and the indulgence index. These results suggest that the multiple motivations of the taxpayer affect the success of the tax measure in terms of requests for invoices with a TIN. This finding must be considered when assessing the success or failure of any fiscal policy that promotes voluntary cooperation. The absence of a single key factor shows that the study of tax behavior is relevant in the design and implementation of measures to combat tax evasion. Besides the factors previously identified by Wilks et al. (2019) - tax benefits, perceptions of justice, and civic duty - the tax administration should not disregard the importance of other motivations such as proximity to the seller/service provider or being unhappy with the use of taxes paid by taxpayers.

The cluster analysis identifies different groups of taxpayers using the four factors identified in this study, showing that individuals are complicated, they are driven by different reasons, and they respond in different ways (Alm, 2019). The results also show that this clustering procedure differentiates the groups in terms of their sociodemographic characteristics, namely, age and education level. The results confirm that different combinations of sociodemographic attributes affect the behavior of taxpayers in relation to requesting an invoice with or without a TIN. Several studies show that tax compliance depends on sociodemographic attributes (e.g. Devos, 2014), but these works indicate the great heterogeneity of individual taxpayer behavior (Alm, 2019). The results emphasize that taxpayers are social creatures, whose behaviors exhibit a diversity marked by their characteristics, which evolve over time.

\section{Conclusions}

The study finds evidence that invoice requests are a complex phenomenon, since it is associated with the intrinsic and extrinsic motivations of taxpayers. Moreover, the results show that different combinations of sociodemographic attributes affect the behavior of taxpayers in relation to requesting an invoice with or without a TIN. This finding suggests the heterogeneous behavior of taxpayers in relation to invoice requests. 
This paper presents two theoretical and practical contributions. First, combating tax evasion remains a contemporary issue considering its implications for the economic development of countries. This work contributes to the knowledge of the reasons that lead citizens to cooperate with tax authorities in pursuing tax evasion, revealing that the attitude of asking for an invoice with a TIN is a complex phenomenon. The results suggest multiple factors that are weighed up by taxpayers, as well as considering their sociodemographic characteristics to interpret their behaviors. As mentioned by Feld et al. (2006), there is a limited amount of empirical and experimental evidence to investigate in detail the impact of positive rewards on tax compliance. Our study contributes to this relatively unexplored field of taxation, through identifying taxpayers' behavior in relation to requesting invoices with a TIN for expenses incurred in certain activity sectors and those that lead them to adopt the opposite attitude, that is, to not request an invoice.

Second, this paper also has practical implications. Understanding taxpayers' behavior is critical to predicting their reactions to the introduction of standards and other voluntary tax cooperation measures. Thus, the results obtained may be used by the government and tax authority in the design and implementation of current and/or future measures to combat tax evasion and interact with taxpayers.

Nevertheless, this study has three possible limitations. First, although questionnaires are a widely used method for analyzing taxpayer decisions regarding tax compliance (Kirchler \& Wahl, 2010), the reliability of the collected data may be somewhat questionable (Alm $\&$ Torgler, 2011). The sensitive nature of information in the tax field may give rise to unreliable answers (Jackson \& Milliron, 1986). Moreover, the relationship between attitudes and behavior is not always direct; it is not unusual for people not to behave according to "what they preach." Second, the sample in this work is not representative of the population of individual taxpayers and only includes PIT residents in Portugal, therefore any extrapolation of the findings may be considered invalid. Third, any interpretation of the results must consider the cultural dimension, making it difficult to extrapolate them to other very different cultural contexts. The literature is fertile with studies that show a strong association between fiscal behavior and national culture (e.g. Guerra \& Harrington, 2018; Richardson, 2008).
This study was carried out from the consumer's perspective, that is, from the viewpoint of the individuals who buy goods or services. For future research, it would be interesting and beneficial to conduct an empirical study from the seller's perspective. The predisposition of sellers to issue an invoice may also be influenced by certain factors, such as the industry and profitability. A study from the seller's perspective will allow tax authorities to understand the factors that induce tax behavior.

\section{References}

AGBETUNDE, L. A., AKINRINOLA, O. O., \& ODINAKACHI, I. (2020). A survey of religiosity, tax morale and compliance among micro, small and medium scale enterprises in Nigeria. Journal of Taxation and Economic Development, 19(1), 35-49.

AJZEN, I., \& FISHBEIN, M. (2005). The influence of attitudes on behavior. In D. Albarracín, B. T. Johnson, \& M. P. Zanna (Eds.). The handbook of attitudes (pp. 173-221). Mahwah, NJ: Lawrence Erlbaum Associates Publishers.

ALLINGHAM, M. G., \& SANDMO, A. (1972). Income tax evasion: A theoretical analysis. Journal of Public Economics, 1(3), 323-338.

ALM, J. (2012). Measuring, explaining, and controlling tax evasion: Lessons from theory, experiments, and field studies. International Tax and Public Finance, 19(1), 54-77.

ALM, J. (2019). What motivates tax compliance? Journal of Economic Surveys, 33(2), 353-388.

ALM, J., JACKSON, B. R., \& MCKEE, M. (1992). Estimating the determinants of taxpayer compliance with experimental data. National Tax Journal, 45(1), 107-114.

ALM, J., \& TORGLER, B. (2011). Do ethics matter? Tax compliance and morality. Journal of Business Ethics, 101(4), 635-651.

ANDREONI, J., ERARD, B., \& FEINSTEIN, J. (1998). Tax compliance. Journal of Economic Literature, 36(2), 818-860.

ANTINYAN, A. \& ASATRYAN, Z. (2020). Nudging for tax compliance: A meta-analysis, CESifo, [Working Paper 
No. 8500]. Munich: Center for Economic Studies and Ifo Institute (CESifo).

BALESTRINO, A. \& GALMARINI, U. (2003). Imperfect tax compliance and the optimal provision of public goods. Bulletin of Economic Research, 55(1), 37-51.

BECKER, G. S. (1968). Crime and punishment: An economic approach. Journal of Political Economy, 76(1), 169-217.

BIRD, R. M. (1992). Tax reform in Latin America: A review of some recent experiences. Latin American Research Review, 27(1), 7-36.

BOBEK, D. D., HAGEMAN, A. M., \& KELLIHER, C. F. (2013). Analyzing the role of social norms in tax compliance behavior. Journal of Business Ethics, 115(3), 451-468.

BOBEK, D. D., ROBERTS, R. W., \& SWEENEY, J. T. (2007). The social norms of tax compliance: Evidence from Australia, Singapore, and the United States. Journal of Business Ethics, 74(1), 49-64.

BORREGO, A. C. (2015). Tax compliance and tax complexity in Portugal: essays on the perception of tax professionals (Doctoral thesis). Universidade do Minho, Braga, Portugal. Retrieved from http://hdl.handle. net/1822/38474

BORREGO, A. C., LOPES, C. M. M., \& FERREIRA, C. M. (2017). Tax professionals' profiles concerning tax noncompliance and tax complexity: Empirical contributions from Portugal. eJournal of Tax Research, 15(3), 424-456.

BROCKMANN, H., GENSCHEL, P., \& SEELKOPF, L. (2015). Happy taxation: Increasing tax compliance through positive rewards? Journal of Public Policy, 36(3), 1-26.

Center for Social and Economic Research (2020). Study and reports on the VAT Gap in the EU-28 Member States: 2020 Final Report [Database], September 2020. Warsaw.

CHU, C. Y. (1990). Plea bargaining with the IRS. Journal of Public Economics, 41(3), 319-33.

CLOTFELTER, C. T. (1983). Tax evasion and tax rates: An analysis of individual returns. The Review of Economics and Statistics, 65(3), 363-373.
CUMMINGS, R. G., MARTINEZ-VAZQUEZ, J., MCKEE, M., \& TORGLER, B. (2009). Tax morale affects tax compliance: Evidence from surveys and an artefactual field experiment. Journal of Economic Behavior \& Organization, 70(3), 447-457.

DAUDE, C., GUTIERREZ, H., \& MELGUiZO, A. (2013). What drives tax morale? A focus on emerging economies. Review of Public Economics, 207(4), 9-40.

DEVOS, K. (2014). Factors influencing individual taxpayer compliance behaviour. Dordrecht: Springer.

DIOGO, T. R. A. (2018). A Interação entre os contribuintes singulares e a administração fiscal e o seu impacto no cumprimento Fiscal (Doctoral Dissertation). Universidade de Lisboa. Lisboa, Portugal.

FABBRI, M., \& WILKS, D. C. (2016). Tax Lotteries: The crowding-out of tax morale and long-run welfare effects. Journal of Legal, Ethical and Regulatory Issues, 19(2), 1-19.

FELD, L. P. \& FREY, B. S. (2007). Tax compliance as the result of a psychological tax contract: The role of incentives and responsive regulation. Law \& Policy, 29(1), 102-120.

FELD, L. P., FREY, B. S., \& TORGLER, B. (2006). Rewarding honest taxpayers? Evidence on the impact of rewards from field experiments. Center for Research in Economics, Management and the Arts, Working Paper No. 2006-16, Zürich: CREMA.

FISS, P. C. (2011). Building better causal theories: a fuzzy set approach to typologies in organization research. Academy of Management Journal, 54(2), 393-420.

FODDY, W. (1996). Como perguntar: Teoria e prática da construção de perguntas em entrevistas e questionários. Oeiras: Celta.

FOOKEN, J., HEMMELGARN, T., \& HERRMANN, B. (2014). Improving VAT compliance - random awards for tax compliance [Working Paper No. 51-2014]. Directorate General Taxation and Customs Union, European Commission.

GUERRA, A., \& HARRINGTON, B. (2018). Attitudebehavior consistency in tax compliance: A cross-national comparison. Journal of Economic Behavior \& Organization, 156, 184-205. 
HEMELS, S., \& FABBRI, M. (2013). “Do You Want a Receipt?” Combating VAT \& RST Evasion with Lottery Tickets. Intertax, 41, 430-443.

Her Majesty's Revenue \& Customs (2012). The UK Tax Gap. London: HMRC.

Her Majesty's Revenue \& Customs (2020). Measuring tax gaps 2020 edition - Tax gap estimates for 2018-19. London: HMRC.

HILL, M. M. \& HILL, A. (2008). Investigação por questionário. Lisboa: Edições Sílabo.

JACKSON, B. R., \& MILLIRON. V. C. (1986). Tax compliance research: Findings, problems and prospects. Journal of Accounting Literature, 5(1), 125-161.

JAMES, S. \& ALLEY, C. (2002). Tax compliance, selfassessment and tax administration. Journal of Finance and Management in Public Services, 2(2), 27-42.

JANSSENS, W., WIJNEN, K., PELSMACKER, P. DE, \& KENHOVE, P. VAN (2008). Marketing research with SPSS. Essex: FT Prentice Hall.

JIMENEZ, P., \& IYER, G. S. (2016). Tax compliance in a social setting: The influence of social norms, trust in government, and perceived fairness on taxpayer compliance. Advances in Accounting, 34(September), 17-26.

KAZEMIER, B., \& VAN ECK, R. (1992). Survey investigations of the hidden economy: Some methodological results. Journal of Economic Psychology, 13(4), 569-587.

KIRCHLER, E. (2007). The economic psychology of tax behaviour. New York: Cambridge University Press.

KIRCHLER, E., \& WAHL, I. (2010). Tax compliance inventory TAX-I: Designing an inventory for surveys of tax compliance. Journal of Economic Psychology, 31(3), 331-346.

LAMBERTON, C. P., DE NEVE, J.-E., \& NORTON, M. I. (2018). The power of voice in stimulating morality: Eliciting taxpayer preferences increases tax compliance. Journal of Consumer Psychology, 28(2), 310-328. doi:https:// doi.org/10.1002/jcpy. 1022
MCBARNET, D. (2001). When compliance is not the solution but the problem: From changes in law to changes in attitude. Australian National University, Centre for Tax System Integrity [Working Paper No. 18]. Retrieved from https://openresearch-repository.anu.edu.au/ bitstream/1885/41635/2/WP18.pdf

MCKERCHAR, M. (2003). The impact of complexity upon tax compliance - A study of Australian personal taxpayers. Australian Tax Research Foundation, 39(1), 1-223.

MITU, N. E. (2016). Taxpayer behaviour: Typologies \& influence factors. Revista de Stiinte Politice, (49), 77-87.

MURPHY, R. (2008). How to calculate the tax not paid by multinational corporations. Norfolk: Tax Research LLP.

Organisation for Economic Co-Operation and Development (2010). Forum on Tax Administration: Small/Medium Enterprise (SME) Compliance Group: Understanding and Influencing Taxpayers' compliance Behavior. Paris. Retrieved from https://www.oecd.org/tax/forum-on-taxadministration/publications-and-products/46274278.pdf

ONU, D., \& OATS, L. (2016). Paying tax is part of life: Social norms and social influence in tax communications. Journal of Economic Behavior \& Organization, 124(1), 29-42.

PALAN, R., MURPHY, R., \& CHAVAGNEUX, C. (2010). Tax havens: How globalization really works. Cornell Studies in Money. Ithaca, NY: Cornell University Press.

PASTOR, D. A. (2010). Cluster analysis. In G. R. Hancock, \& R. O. Mueller, (Eds.), The reviewer's guide to quantitative methods in the social sciences (pp. 41-54). New York: Routledge.

PEREIRA, M. (2018). Fiscalidade (6th ed.). Coimbra: Almedina.

PEREZ, L., \& HUMPHREYS, B. (2013). The 'who and why' of lottery: Empirical highlights from the seminal economic literature. Journal of Economic Surveys, 27(5), 915-940.

PICKHARDT, M., \& PRINZ, A. (2014). Behavioral dynamics of tax evasion - A survey. Journal of Economic Psychology, 40(1), 1-19. 
RACZKOWSKI, K. (2015). Measuring the tax gap in the European economy. Journal of Economics \& Management, 21(3), 58-72.

RICHARDSON, G. (2008). The relationship between culture and tax evasion across countries: Additional evidence and extensions. Journal of International Accounting, Auditing and Taxation, 17(2), 67-78.

RICHARDSON, M., \& SAWYER, A. J. (2001). A taxonomy of the tax compliance literature: Further findings, problems and prospects. Australian Taxation Forum, 16(2), 137-320.

ROBBINS, B., \& KISER, E. (2020). State coercion, moral attitudes, and tax compliance: Evidence from a national factorial survey experiment of income tax evasion. Social Science Research, 91, (1-21).

ROTH, J. A., SCHOLZ, J. T., \& WITTE, A. D. (1989) (eds.). Taxpayer compliance: An agenda for research. 1st ed., Philadelphia: University of Pennsylvania Press.

SÁ, C. I. B. (2013). Fatores determinantes da moral tributária em Portugal: Uma análise através da aplicação de um modelo de equaçóes estruturais (Doctoral Thesis). Universidade de Coimbra, Coimbra, Portugual.

SÁ, C., GOMES, C. \& MARTINS, A. (2016). Tax morale dimensions analysis in Portugal and Spain. World Academy of Science, Engineering and Technology. International Journal of Social, Behavioral, Educational, Economic, Business and Industrial Engineering, 10(12), 3863-3869.

SANSON, A., MONTGOMERY, B., GAULT, U., GRIDLEY, H., \& THOMSON, D. (1996). Punishment and behaviour change: An Australian Psychological Society position paper. Australian Psychologist, 31(3), 157-165.

SCHMÖLDERS, G. (1959). Fiscal psychology: A new branch of public finance. National Tax Journal, 12(4), 184-193.

SCHNEIDER, F. (2005). Shadow economies around the world: what do we really know? European Journal of Political Economy, 21(3), 598-642.

SCHWARTZ, R., \& ORLEANS, S. (1967). On legal sanctions. University of Chicago Law Review, 34(2), 274-300.
SEKARAN, U., \& BOUGIE, R. (2016). Research methods for business: A skill building approach (7th ed.). Chichester, West Sussex: John Wiley \& Sons.

SLEMROD, J. (2007). Cheating ourselves: The economics of tax evasion. Journal of Economic Perspectives, 21(1), 25-48.

SLEMROD, J. (2019). Tax compliance and enforcement. Journal of Economic Literature, 57(4), 904-954.

SLEMROD, J., \& S. YITZHAKI (2002). Tax avoidance, evasion, and administration. In A. J. Auerbach, \& M. Feldstein (eds.), Handbook of Public Economics, (Vol. 3, Cap. 22, pp. 1423-1470). Amsterdam: Elsevier.

SPEKLÉ, R. F., \& WIDENER, S. K. (2018). Challenging issues in survey research: discussion and suggestions. Journal of Management Accounting Research, 30(2), 3-21.

SPICER, M. W. (1974). A behavioral model of income tax evasion (Doctoral Dissertation). The Ohio State University, Columbus, United States.

SRINIVASAN, T. (1973). Tax evasion: A model. Journal of Public Economics, 2(4), 339-346.

STRÜMPEL, B. 1969. The contribution of survey research to public finance. In: A. T. Peacock (eds.), Quantitative Analysis in Public Finance (pp. 13-32), New York: Praeger.

TORGLER, B. (2003). Tax morale, rule-governed behaviour and trust. Constitutional Political Economy, 14(2), 119-140.

TORGLER, B. (2007). Tax Compliance and tax morale: A theoretical and empirical analysis. Cheltenham: Edward Elgar Publishing.

WEBLEY, P., ADAMS, C., \& ELFFERS, H. (2006). Value added tax compliance. In E. J. McCaffery, J. B. Slemrod (Eds.), Behavioral public finance (pp. 175-205). New York: Russell Sage Foundation.

WILKS, D. C., CRUZ, J., \& SOUSA, P. (2019). "Please give me an invoice": VAT evasion and the Portuguese tax lottery. International Journal of Sociology and Social Policy, 39(5/6), 412-426.

YITZHAKI, S. (1974). A note on Income tax evasion: A theoretical analysis. Journal of Public Economics, 3(2), 201-202. 


\section{Financial support:}

Tiago Andrade Diogo and António Samagaio acknowledge the financial support from FCT (Fundação para a Ciência e a Tecnologia, Portugal) through the Advance Research Centre (project UID/SOC/04521/2020).

\section{Conflicts of interest:}

The authors have no conflict of interest to declare.

\section{Copyrights:}

RBGN owns the copyrights of this published content.

\section{Plagiarism analysis:}

RBGN performs plagiarism analysis on all its articles at the time of submission and after approval of the manuscript using the iThenticate tool.

\section{Authors:}

1. João Minas Pinheiro, MSc in Accounting, Taxation, and Corporate Finance, Instituto Superior de Economia e Gestão, Universidade de Lisboa, Lisbon, Portugal

E-mail: joao.minas.pinheiro@gmail.com

2. Tiago Andrade Diogo, Ph.D in Management, Instituto Superior de Economia e Gestáo, Universidade de Lisboa, ADVANCE, Lisbon, Portugal E-mail: tiagodiogo@iseg.ulisboa.pt

3. António Samagaio, Ph.D in Management, Instituto Superior de Economia e Gestão, Universidade de Lisboa, ADVANCE, Lisbon, Portugal

E-mail: antonio.samagaio@iseg.ulisboa.pt

\section{Authors' Contributions:}

$\mathbf{1}^{\text {st }}$ author: Definition of research problem; Development of hypotheses or research questions (empirical studies); Development of theoretical propositions (theoretical work); Definition of methodological procedures; Data Collection; Literature review; Statistical analysis; Critical revision of the manuscript; Manuscript writing.

$2^{\text {nd }}$ author: Definition of research problem; Development of hypotheses or research questions (empirical studies);

Development of theoretical propositions (theoretical work); Definition of methodological procedures; Literature review; Critical revision of the manuscript; Manuscript writing.

$3^{\text {rd }}$ author: Definition of research problem; Definition of methodological procedures; Statistical analysis; Analysis and interpretation of data; Critical revision of the manuscript; Manuscript writing. 